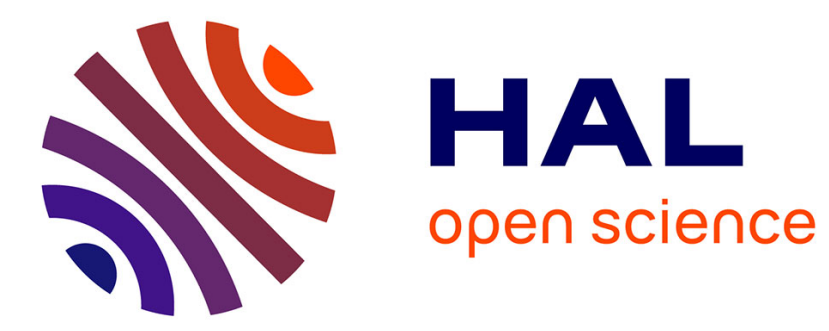

\title{
Modelling Metal-Humic Substances/Surface Systems: Reasons for Success, Failure and Possible Routes for Peace of Mind
}

Pascal E. Reiller

\section{- To cite this version:}

Pascal E. Reiller. Modelling Metal-Humic Substances/Surface Systems: Reasons for Success, Failure and Possible Routes for Peace of Mind. Mineralogical Magazine, 2012, 76 (7), pp.2643-2658. 10.1180/minmag.2012.076.7.02 . cea-00766089

\section{HAL Id: cea-00766089 https://hal-cea.archives-ouvertes.fr/cea-00766089}

Submitted on 12 Sep 2019

HAL is a multi-disciplinary open access archive for the deposit and dissemination of scientific research documents, whether they are published or not. The documents may come from teaching and research institutions in France or abroad, or from public or private research centers.
L'archive ouverte pluridisciplinaire HAL, est destinée au dépôt et à la diffusion de documents scientifiques de niveau recherche, publiés ou non, émanant des établissements d'enseignement et de recherche français ou étrangers, des laboratoires publics ou privés.

\section{(ㅇ)(1) $\$$}

Distributed under a Creative Commons Attribution - NonCommercial - NoDerivatives $\mid 4.0$ 


\title{
Modelling Metal-Humic Substances/Surface Systems: Reasons for Success, Failure and Possible Routes for Peace of Mind
}

\author{
Pascal E. Reiller
}

Commissariat à l'Energie Atomique et aux énergies alternatives, CE Saclay, CEA, DEN, DANS, DPC,

SEARS, Laboratoire de développement Analytique Nucléaire Isotopique et Elémentaire, Bâtiment 391, PC

33, F-91191 Gif-sur-Yvette CEDEX, France

Mineralogical Magazine 76 (7), 2643-2658.

http://doi.org/10.1180/minmag.2012.076.7.02

\section{ABSTRACT}

Iron oxides and oxy-hydroxides are commonly of considerable importance in the sorption of ions onto rocks, soils and sediments. They can be the controlling sorption phase even if they are present in relatively small quantities. In common with other oxides and clay minerals, the sorption $\mathrm{pH}$-edge of metals is directly linked to their hydrolysis: the higher the residual charge on the metal ion, the lower the $\mathrm{pH}$-edge. Modelling of this process has been successfully carried out using different microscopic or macroscopic definitions of the interface (e.g. surface complexation or ion exchange models that may or may not include mineralogical descriptions). The influence of organics on the sorption of many metals is significant. This organic material includes simple organic molecules and more complex exopolymeric substances (e.g., humic substances) produced by the decay of natural organic matter. Sorption of these organics materials to mineral surfaces has also been the subject of a large body of work. The various types of organics do not share the same affinities for minerals in general, and for iron oxides and oxy-hydroxides in particular. In those cases in which successful models of the component binary systems (i.e., metal/surface, metal/organic, organic/surface) have been developed, the formation of mixed surface complexes, the evolution of the surface itself, the addition order in laboratory systems, and the evolution of natural organic matter fractions during sorption, have often precluded a satisfying description of the metal/surface/organic ternary system over a sufficiently wide ranges of parameter values (i.e. $\mathrm{pH}$, ionic strength, concentration of humic substances). This manuscript describes the reasons for some successes and failures in the modelling of the ternary systems. Promising recent advances and possible methods of providing more complete description of these intricate systems are also discussed. 


\section{INTRODUCTION}

Natural organic matter (NOM) exerts a significant influence on the sorption of metals onto minerals surfaces in soils and sediments. Its influence on the migration behaviour of radionuclides has been recognized in many studies. Examples include the migration of plutonium in soils following the nuclear detonation at Nagasaki (Mahara and Miyahara, 1984; Mahara et al., 1988; Mahara and Kudo, 1995; Fujikawa et al., 1999) and the Chernobyl accident (Matsunaga et al., 2004); the migration of actinide-group elements in soils at Oak Ridge National Laboratory (McCarthy et al., 1998a,b); and the interaction of radionuclides with mining debris (wood and oil) at the Nevada Test Site (Zhao et al., 2011). Natural organic matter is released by the decay of biological material through complex mechanisms. Although these have been studied for a many years, aspects of the composition and structure of NOM remains as puzzles for scientists. Achard (1786) proposed alkaline-extracted humic substances (HS) as simple and useful analogues for NOM more than two centuries ago. Modern definitions of humic substances are still linked to his extraction methods (Stevenson, 1982; MacCarthy, 2001b). The organic molecules produced during the diagenesis of biological material are so complex that $\mathrm{HS}$ are still not fully characterized (MacCarthy, 2001a,b). Briefly, HS are composed of humine, which is insoluble in all pH conditions; humic acid (HA), which is insoluble in acidic $\mathrm{pH}$ conditions; and fulvic acid (FA), which is soluble in all $\mathrm{pH}$ conditions and is retained on polyacrylic resins (XAD-8) (Stevenson, 1982; Aiken et al., 1985; Ghabbour and Davies, 2001).

The use of HS in studies of the complexation and sorption properties of NOM has generated a large body of work. Although HS remains poorly characterized, some general features have emerged. From a structural point of view, Wershaw (1986, 1989, 1993, 1999) proposed that NOM was made up of aggregates of small molecules. As part of NOM, HS also contain aggregates of small molecules (Aiken and Malcolm, 1987; Chin et al., 1994; Plancque et al., 2001; Kujawinski et al., 2002b; These et al., 2004) and organic nanometre-scale entities (Bouby et al., 2002; Baalousha and Lead, 2007; d'Orlyé and Reiller, 2012) with a fractal organization (Österberg et al., 1995; Senesi et al., 1997; Rice et al., 1999), which can clump together to form larger aggregates (Pinheiro et al., 1996; Manning and Bennett, 2000; d'Orlyé and Reiller, 2012). The 'micelle-like' or 'membranelike' paradigm proposed by Wershaw $(1986,1993,1999,2000)$ may initially appear too organized to reflect the inherent heterogeneity of NOM or HS, but the recognition of a degree of organisation in NOM aggregates undoubtedly stems from Wershaw's work. Analyses by mass spectroscopy (Plancque et al., 2001; Kujawinski et al., 2002a; These et al., 2004) and nuclear magnetic resonance (NMR) techniques (Kim et al., 2003; Simpson et al., 2003) have shown the extensive heterogeneity of NOM, and this is also corrobarated by recent sequential extraction protocols using high performance size exclusion chromatography (HP-SEC) coupled to mass spectroscopy and NMR (Nebbioso and Piccolo, 2011, 2012). 
Figure 1 shows a schematic representation of a humic acid aggregate. Following Nachtegaal (2003), carboxylic acid groups and other hydrophilic and fatty acids are located on the outside of the aggregates, whereas aromatic and hydrophobic groups occupy the centres. The compositions of NOM and HS are dominated by carbon, oxygen and hydrogen, with minor sulfur and nitrogen; their strong reactivity towards metal ions and minerals is mainly driven by carboxylate and phenolate functional groups, which imply a weak selectivity and comparable interaction for analogous cations (van Dijk, 1971; Reiller and Buckau, 2012). Although relatively large molecular masses have been reported for HS (mainly based on HP-SEC studies using globular proteins), the terms polymer or polyelectrolyte seem inadequate to describe them as no repetitive structure, or welldefined building blocks, have been identified. Observations of sorbed HS by atomic force microscopy (AFM) have revealed that they occur as small entities that aggregate and disaggregate with changes in $\mathrm{pH}$ and ionic strength (Maurice and Namjesnik-Dejanovic, 1999; Plaschke et al., 1999), rather than as the coiled or elongated structure that are typical of polymers (Ogoshi and Chujo, 2005). The distribution of charges and the binding strengths of the alkaline and alkaline-earth metals are also very different between polymers and humic acids (van den Hoop et al. (1990). A reversible disruption of the structure under the influence of acids has been clearly demonstrated (Piccolo et al., 2000, 2001). Nevertheless, the ionic strength dependence of HA sorption, and to a minor extent of FA sorption, has some commonalities with polyelectrolytes (Blaakmeer et al., 1990; Böhmer et al., 1990). 


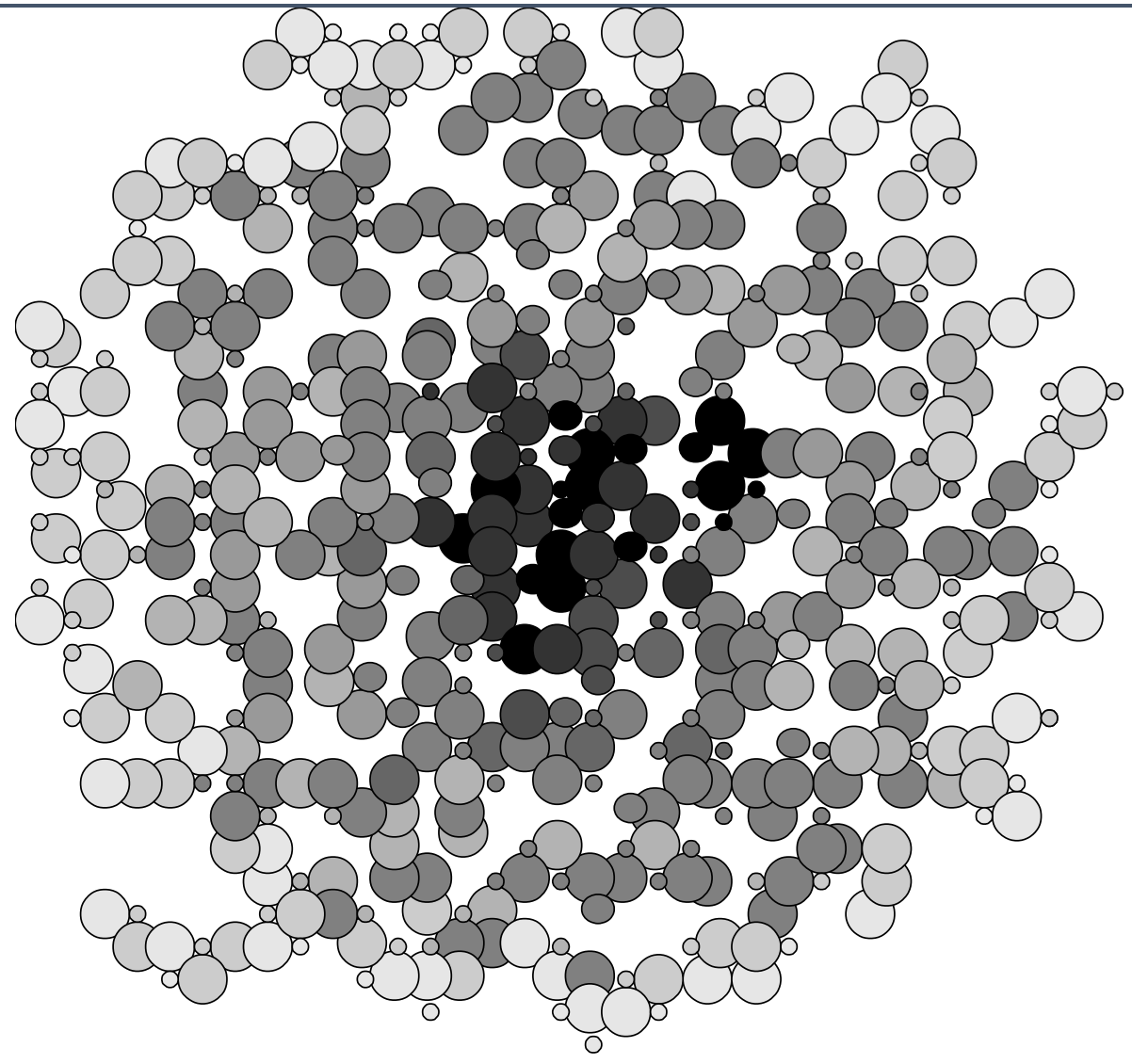

Figure 1. A schematic representation of a heterogeneous humic acid aggregate composed of different entities of different sizes. The entities can be viewed as molecules or aggregates of molecules. The grey shades represent the differences in hydrophobicity, with darker entities being more hydrophobic.

A simple approach in modelling a complex system is to test the linear additivity of its different binary components (Zachara et al., 1994; Vermeer et al., 1999). In this case these systems are: (1) the metal/HS complexation system (which also includes systems in which metals are complexed by inorganic ligands, i.e. $\left.\mathrm{OH}^{-}, \mathrm{CO}_{3}{ }^{2-}, \mathrm{PO}_{4}{ }^{3-} \ldots\right)$; (2) the $\mathrm{HS} /$ surface sorption system; and (3) the metal/surface sorption system. The assumption of linear additivity requires these systems to be acting simultaneously and independently, without deviation due to modifications of one of the constituents or the formation of a ternary surface complex. It is worthwhile noting that in some successful models of ternary systems (e.g. Zachara et al., 1994; Heidmann et al., 2005), the linear additivity of the binary systems does not always represent the behaviour of ternary systems on a sufficiently large parametric domain (e.g. pH, ionic strength, metal concentration; Robertson and Leckie, 1994; Vermeer et al., 1999). Indeed, Tipping et al. (1983) came to the conclusion that there is a need to account for "the creation of extra uptake sites of relatively high affinity" when surface and HS interact to explain their results. Following Lavoisier (1789, chapter XIII), these sites cannot be created from nothing (creation ex nihilo), but are more probably produced (creation ex materia) by the sorption process (Janot et al., 2011; Janot, 2011) and conformational rearrangement (Amal et al., 1992; Au et al., 1999). 
In this paper binary metal/HS and HS/surface systems are reviewed, and different ternary metal/HS/surface systems are described. The focus is primarily on radionuclides, but also includes illustrative examples of other metal ions. The reasons that prevent the linear additivity of binary system from properly described ternary systems are identified, and techniques that have the potential to produce more realistic models of the ternary systems are described.

\section{BINARY SYSTEMS}

\subsection{The metal/HS binary system}

The interaction of HS with metal ions follows the Irving and Williams (1948) series (Schnitzer and Skinner, 1966, 1967; Kerndorff and Schnitzer, 1980): alkali-metal interactions are weak (van den Hoop et al., 1990; d'Orlyé and Reiller, 2012) and the strongest interaction is with $\mathrm{M}^{4+}$ elements (Reiller, 2005; Reiller et al., 2008). The interaction is weakly selective between analogous metals (vide supra). For the lanthanides $(\mathrm{Ln})$ and actinides $(\mathrm{An})$, the strength of interaction increases from $\mathrm{M}(\mathrm{V}), \mathrm{NpO}_{2}{ }^{+}(\mathrm{Kim}$ and Sekine, 1991; Seibert et al., 2001); to $\mathrm{M}(\mathrm{III})$ and $\mathrm{M}(\mathrm{VI}), \mathrm{Eu}^{3+}, \mathrm{Sm}^{3+}, \mathrm{Am}^{3+}, \mathrm{Cm}^{3+}, \mathrm{UO}_{2}{ }^{2+}$ (Czerwinski et al., 1994, 1996; Sonke, 2006; Pourret et al., 2007; Sachs et al., 2007; Marang et al., 2008; Reiller et al., 2011a); to M(IV), $\mathrm{Th}^{4+}, \mathrm{U}^{4+}, \mathrm{Np}^{4+}, \mathrm{Pu}^{4+}$ (Nash and Choppin, 1980; Reiller et al., 2003; Reiller, 2005; Reiller et al., 2008; Beneš, 2009; Szabó et al., 2010; Stockdale et al., 2011). Modelling of the metal/HS binary systems is possible using semi-empirical techniques (Hummel, 1997; Tipping, 2002; Reiller and Buckau, in press). Due to the intrinsic heterogeneity of the systems, the strict application of thermodynamics is often awkward. In particular, it is difficult to produce thermodynamic models. In particular, it is difficult to unequivocally define a standard state for a mixture of molecules in which the composition and possible interactions between the components are unknown. Extra-thermodynamic assumptions are therefore made (e.g. varying operational constants with physico-chemical parameters such as $\mathrm{pH}$ and ionic strength), that hide the variation of an extensive parameter [e.g. number of available sites (Reiller and Buckau, 2012)]. These models allow satisfactory operational description of the experimental results as long as the defined 'HS object' is not modified during the reaction (e.g. by complexation or sorption). However, due to the possible modification of HS during complexation reactions (Caceci and Billon, 1990; Plaschke et al., 2002; Christl and Kretzschmar, 2007), semi-empirical complexation models must be applied with great care.

In some cases, modifications are not important. Reiller et al. (2011b) showed that both the $\mathrm{Eu}$ (III)-HS complexation strength and complex symmetry were comparable for different HP-SEC fractions of HA. In contrast, Claret et al. (2008) clearly showed that both the $\mathrm{Eu}(\mathrm{III})$-HS complexation strength and complex symmetry were greatly modified for fractions of $\mathrm{HA}$ that have undergone sorption onto $\mathrm{a}-\mathrm{Al}_{2} \mathrm{O}_{3}$. This leads to questions about the modifications during sorption in the HS/surface binary system. 


\subsection{The HS/surface system}

There is a large body of work which describes the sorption properties of HS using simple models including small organic molecules, polymers or polyelectrolytes, however, these simple representations do not adequatly represent the sorption behaviour of HS. Due to the relative abundance of carboxylate functional group, the sorption of HS reaches a maximum around the $\mathrm{pK}$ of carboxylic acids, and it decreases with increasing $\mathrm{pH}$ (Tipping, 1981a, 1981b; Gu et al., 1994; Ochs et al., 1994; Vermeer et al., 1998; Reiller et al., 2002; Claret et al., 2008). In this respect it follows the behaviour of weak acids in general (Blesa et al., 1984; Dzombak and Morel, 1990; Marmier and Fromage, 2000) and of simple carboxylic organic acids in particular (Davis and Leckie, 1978; Gu et al., 1995; Evanko and Dzombak, 1998; Borah et al., 2011). The importance of catechol functional groups on the sorption behaviour of HS should not, however, be underestimated (Borah et al., 2011; Gu et al., 1995).

Although the structure of HS is not strictly polymeric, the sorption behaviour of HS on minerals has commonalities with polyelectrolytes, particularly with respect to the influence of ionic strength. At low concentration [i.e. $C<10^{-3} \mathrm{~mol} / \mathrm{L}$ (Szekeres et al., 1998)], when simple organic acids are undergoing competition with the background electrolyte, i.e., when a decrease of sorption when the ionic strength increases (Schulthess and McCarthy, 1990; Mesuere and Fish, 1992; Ali and Dzombak, 1996), the sorption of HS, and particularly HA, increases with ionic strength (Murphy et al., 1994; Schlautman and Morgan, 1994; Au et al., 1999; Reiller et al., 2002; Weng et al., 2006; Janot et al., 2012). The influence of lateral hydrophobic interactions between the humic entities is also important (Ochs et al., 1994; Nachtegaal, 2003). Fulvic acids, which form aggregates of lesser dimension than those of HA, show intermediate behaviour as no, or only weak, influence of ionic strength has been demonstrated (Schlautman and Morgan, 1994; Filius et al., 2000; Reiller et al., 2002). This can be linked to the particulate nature of HA and the decrease in the Debye lengths of both the surface and HS aggregates (a charge screening effect).

The combination of these specific and non-specific (aggregation, lateral interactions) properties that influence the sorption of HS onto surfaces produces a subtle balance between surface complex formation and electrostatic forces that depends on three factors: (1) the $\mathrm{pH}$ of the solution, which controls the ionization and surface charge of the HS aggregates and surface, respectively; (2) the ionic strength, which controls the surface potential and of the conformation of HS aggregates; and (3) the free energy of the specific adsorption of the HS aggregates. As long as the surface charges are opposite $\left(\mathrm{pH}<\mathrm{pH}_{\mathrm{pzc}}\right.$, HS are negative and the surface is positive), the first two factors encourage sorption. The last factor implies an extension of this sorption domain, and explains why sorption is not nil at the point of zero charge of the mineral surface and why it extends up to more basic $\mathrm{pH}$ values, even if the electrostatic contribution is not favourable. This influence of the specific interaction is observed, for instance for sorption of borate or silicate onto iron oxides 
(Blesa et al., 1984; Marmier and Fromage, 2000), for various benzoic acids (Davis and Leckie, 1978; Gu et al., 1995; Evanko and Dzombak, 1998), for polyelectrolytes (Chibowski and Wisniewska, 2002) and for humic substances (vide supra). As the sorption of $\mathrm{HS}$ is driven by interactions of carboxylate and to a lesser extent phenolate groups with hydroxylated surface sites (Gu et al., 1995; Yoon et al., 2004), but also by non-specific interactions, modelling is not trivial.

Humic substances/surface binary systems have been extensively modelled. The largest proportion is surface complexation models that suggest ligand exchange on hydroxylated sites (e.g. Filius et al., 2000) based on spectroscopic evidence (Gu et al., 1995; Wershaw et al., 1995). In these studies, the HA were mostly defined as indistinct mixtures of entities that undergo surface complexation, although some authors have attempted to account for their complexity and heterogeneity. Humic substances can be conceptualized as particules that are chemically fixed to a surface by one or more of their functional groups. The remainder of the particle is weakly bound by lateral hydrophobic interactions. According to Ochs et al. (1994) the lateral interaction produces a membrane-like structure similar to that described by Wershaw (1986). In this model, the number of mineral surface sites is overcompensated by sorbed humic sites (Vermeer, 1996; Au et al., 1999; Reiller et al., 2002). Such surface particles have been observed in atomic force microscopy (Maurice and Namjesnik-Dejanovic, 1999; Namjesnik-Dejanovic and Maurice, 2000).

As NOM and HS are heterogeneous mixtures, sorptive fractionation occurs, and this depends on the nature of both the organic extract and the mineral surface (Davis and Gloor, 1981; Gu et al., 1994; Kaiser and Zech, 1997; Meier et al., 1999; NamjesnikDejanovic et al., 2000; Hur and Schlautman, 2003, 2004a, 2004b; Reiller et al., 2006; Claret et al., 2008; Pitois et al., 2008; Janot et al., 2012), and on equilibration time (Gu et al., 1994; van de Weerd et al., 1999). This has been characterized by techniques including SEC, UV-Visible, time-resolved luminescence spectroscopy, and asymmetric flow-field flow fractionation, for different ternary systems. As a result of the reduction in the dielectric constant of water at the surface of a mineral (Booth, 1951), one can also assume that the more hydrophilic entities have a low affinity for the surface, leading to an over representation of hydrophobic entities, and a higher molecular mass fraction on minerals. This has been observed experimentally (Gu et al., 1995; van de Weerd et al., 1999). The evolution of sorption with time is also of interest. Rapidly sorbed low molecular mass fractions (Ochs et al., 1994; Avena and Koopal, 1999), are replaced by higher molecular mass fractions (Gu et al., 1994; van de Weerd et al., 1999; Pitois et al., 2008) following slow kinetics (Ochs et al., 1994; Avena and Koopal, 1998; Vermeer and Koopal, 1998) that are function of the NOM to mineral surface mass ratio (van de Weerd et al., 1999). In the case of metal oxides, exchange reactions between fractions of different molecular mass and hydrophobicity proceed more rapidly in the aromatic and low molecular mass fractions (Avena and Koopal, 1999; Pitois et al., 2008). The origin of the slow kinetics step can be viewed as slow exchange between non-sorbed hydrophobic humic entities and those that are already sorbed (Kaiser and Guggenberger, 2000). These mechanisms are thought to 
be the cause of the modification of humic fraction during transport in sediment column experiments (Johnson et al., 2002).

An important outcome of this sorptive fractionation is that the 'HS object', as defined in a model, contains material that can fractionate and therefore the properties of the HS can evolve. The differences reported by Claret et al. (2008) between their original Eu(III)-HA complex and $\mathrm{Eu}(\mathrm{III})$ complexed by $\mathrm{HA}$ fractionated onto $\mathrm{a}-\mathrm{Al}_{2} \mathrm{O}_{3}$, result from these fractionation phenomena. In this case, the interaction between the fractionated HA and $\mathrm{Eu}(\mathrm{III})$ is less significant than that between the original $\mathrm{HA}$ and $\mathrm{Eu}(\mathrm{III})$. By contrast, Heidmann et al. (2005) showed that the $\mathrm{Cu}$ (II)-FA interaction after fractionation onto kaolinite was more significant than that before fractionation. This is reminiscent of the 'creation of sites' in Tipping et al. (1983) for the $\mathrm{Cu}(\mathrm{II}) / \mathrm{HA} /$ goethite system.

Different strategies can be used to model this apparent increase of affinity. Weng et al. (2007) proposed an adaptation of the metal/HA binary system free energy during sorption. A strong hypothesis is that the free energy change associated with humic substance aggregates at equilibrium has the same chemical potential, including electrostatic effects, sorbed to the surface and remaining in solution. In other words, the defined 'humic object' is the same in solution and at the surface but its free energy is changed due to sorption. It has been shown, however, that there are changes in the composition of HA due to sorptive fractionation (vide supra). A schematic view of the sorptive fractionation process is proposed in Figure 2; the humic acid aggregate leaves the more hydrophobic fraction onto the surface as the lower molecular mass and hydrophilic fractions are released in the bulk.

The quantification of functionality after sorptive fractionation was proposed by Janot et al. $(2010,2011)$ for a HA by spectrophotometric titration. In the framework of the non-ideal competitive adsorption-Donnan (NICA-Donnan) model (Kinniburgh et al., 1999), it was shown that a substantial proportion of the more acidic functionality (those with the lower $\log _{10} \tilde{K}_{H}$ in the framework of the NICA-Donnan model) remained in suspension, and that this has an influence on the metal-HS $S_{\text {sorbed }}$ and metal-HS free complexes, and on the metal/HS/surface ternary system. This quantification relies on the operational relationship between the optical properties of humic substances and the potentiometric titration. This operational relationship is less elegant and thermodynamically consistent than the proposition of Weng et al. (2007), but it accounts for the observed modification of functionality and composition of the 'HA objects' during sorption. It should be noted that this relationship still needs to be determined for each HS. 


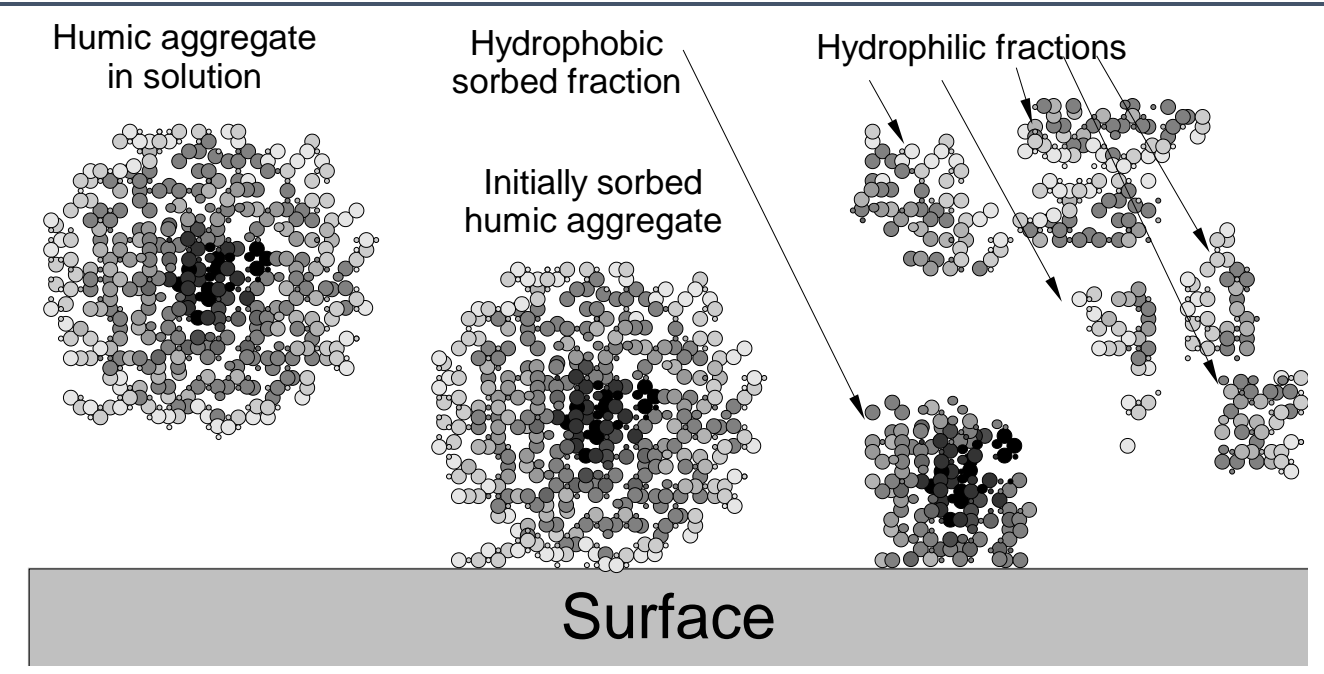

Figure 2. A schematic representation of sorptive fractionation of the NOM aggregate (see Figure 1) onto mineral surfaces.

\subsection{The metal/surface system}

The binary metal/surface system has been widely described in the literature and only the basic properties that are necessary to understand ternary systems will be discussed.

The sorption $\mathrm{pH}$-edge of metals on minerals is closely related to their first hydrolysis constant (Bradbury and Baeyens, 2005a, 2005b, 2009). As shown schematically in Figure 3 , at trace concentrations sorption commonly occurs at $\mathrm{pH} \mathrm{8-10} \mathrm{for} \mathrm{AnO}_{2}{ }^{+}$(Turner et al., 1998); at pH 5-7 for Ln/An ${ }^{3+}$ (Fairhurst et al., 1995; Rabung et al., 2000, 2005; Tan et al., 2008; Janot et al., 2011); at pH 3-5 for $\mathrm{UO}_{2}{ }^{2+}$ (Waite et al., 1994; Lenhart and Honeyman, 1999); and at $\mathrm{pH} 2-3$ for $\mathrm{An}^{4+}$ (Murphy et al., 1999; Takahashi et al., 1999; Reiller et al., 2002, 2005; Romanchuk et al., 2011). The modelling was mainly done through surfacecomplexation models of various kinds (Hiemstra et al., 1989a, 1989b; Davis and Kent, 1990; Dzombak and Morel, 1990), with ion-exchange models (Alliot et al., 2005a, 2005b, 2006; Motellier et al., 2003; Tertre et al., 2010), and also with mixed ion-exchange/nonelectrostatic surface-complexation strategies (Bradbury and Baeyens, 2002, 2005a; Bradbury et al., 2005; Bradbury and Baeyens, 2009).

The influence of ionic strength depends on the nature of the minerals. For well-defined oxides there are mostly no influences on the sorption of metals (Zachara et al., 1994; Reiller et al., 2002; Janot, 2011). For clays, however, an ionic strength influence is clearly evident (Zachara et al., 1994; Bradbury and Baeyens, 2002). 


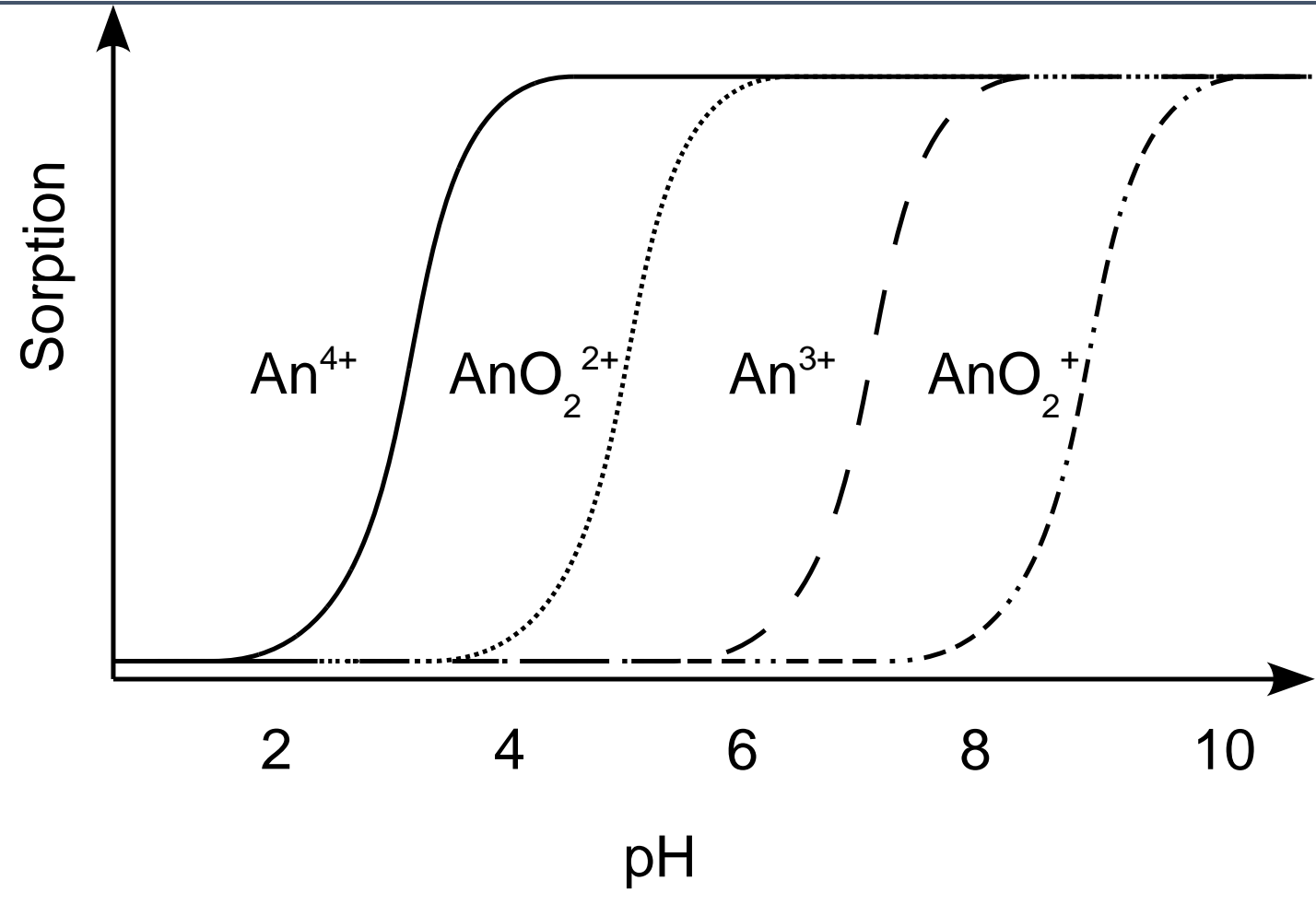

Figure 3. A schematic comparison of actinides $\mathrm{pH}$-edge at trace concentration for $\mathrm{An}(\mathrm{V})\left(\mathrm{AnO}_{2}{ }^{+}\right), \mathrm{An}^{3+}, \mathrm{An}(\mathrm{VI})\left(\mathrm{AnO}_{2}{ }^{2+}\right)$, and $\mathrm{An}^{4+}$.

\section{THE TERNARY METAL/HS/SURFACE SYSTEMS \\ 3.1. Influence of sorptive fractionation of $H S$}

In ternary systems, in which metal cations, minerals and NOM coexist, there are complicated interactions among the three components; these interactions can be competitive or synergistic. The sorption of metals in these ternary systems generally increases before the mineral sorption edge compared to the metal/surface binary system, due the sorption of metal-HS complexes, and then decreases after the $\mathrm{pH}$-edge due to desorption of HS. The metal sorption eventually decreases at more alkaline $\mathrm{pH}$ values. This general pattern is found for all metals and, in particular, for all the redox states of radionuclides (Figure 4) [e.g. Ln/An(III) (Fairhurst et al., 1995; Tan et al., 2008; Janot et al., 2011), U(VI) (Payne et al., 1996; Zeh et al., 1997; Lenhart and Honeyman, 1999; Krepelova et al., 2006), and An(IV) (Takahashi et al., 1999; Reiller et al., 2002, 2005)].

The results of the modelling strategies depend on the nature of the mineral phases. For clay minerals, linear additive models are relatively successful (Dalang et al., 1984; Zachara et al., 1994; Heidmann et al., 2005). For oxides, linear additive binary models do not always produce reliable and adequate description of ternary systems across wide ranges of $\mathrm{pH}$, ionic strength, metal and HS activities (Robertson and Leckie, 1994; Robertson, 1996; Vermeer et al., 1999; Christl and Kretzschmar, 2001). Tipping et al. (1983) proposed that the reactivity of sorbed HA was modified during sorption and that 'extra uptake sites' with higher reactivity were created on the surface, or more probably, 
were exposed during sorptive fractionation. Binary linear additivity under-predicts metal sorption in the ternary systems above the sorption pH-edge (Vermeer et al., 1999; Christl and Kretzschmar, 2001). This may be related to the formation of ternary surface complexes, as is observed in many simple organic molecules (Schindler, 1990, and references therein; Alliot et al., 2005a, 2005b, 2006).

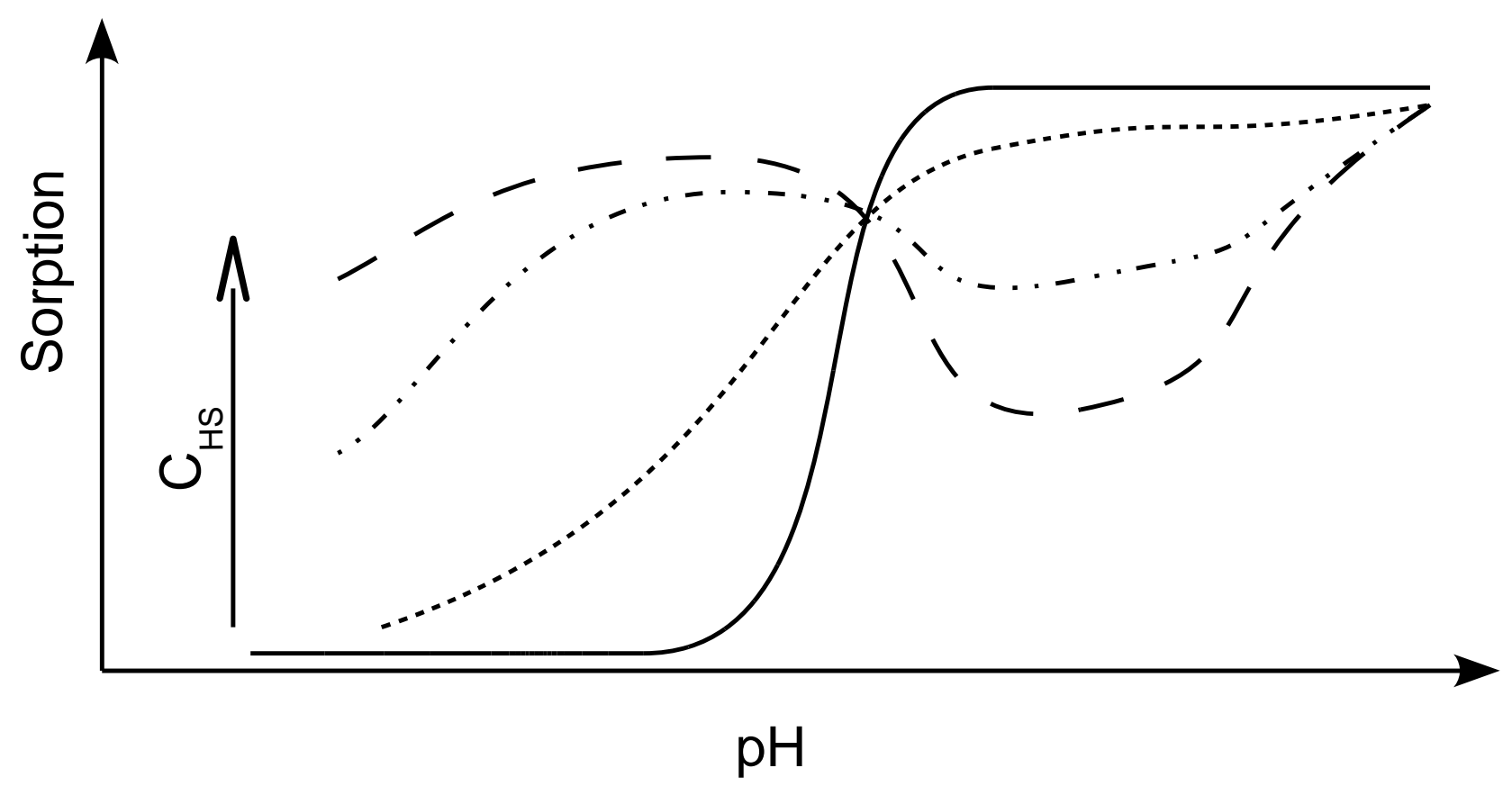

Figure 4. A schematic representation of the variation in metal sorption onto mineral surfaces with increasing concentration of humic substances $\left(\mathrm{C}_{\mathrm{HS}}\right)$. The dotted, dashed-dot-dot, and dashed line represent an increasing concentration of humic substances.

In well-defined oxides minerals an increase of ionic strength leads to an increase in metal sorption, which can in turn be related to an increase in HS sorption - e.g. $\mathrm{Co}(\mathrm{II}) / \mathrm{HA} / \mathrm{gibbsite}$ system (Zachara et al., 1994) and Eu(III)/HA/alumina system (Janot, 2011). As there is a clear effect of ionic strength on metal sorption in the case of some clays - e.g. Co(II)/HA/clay (Zachara et al., 1994) -, it is not easy to discriminate between the different effects of ionic strength on both metal and HS.

Another factor is the influence of metal/HS complexation on the sorption of HS onto minerals. This has been shown for some systems [e.g. the $\mathrm{Pb}$ (II)/FA system (Heidmann et al., 2005) and the $\mathrm{Eu}(\mathrm{III}) / \mathrm{HA}$ (Janot, 2011)], but is not common to all systems [e.g. the $\mathrm{Cu}(\mathrm{II}) / \mathrm{FA}$ system (Heidmann et al., 2005)]. Heidmann et al. (2005) noted that the difference between $\mathrm{Cu}(\mathrm{II}) / \mathrm{FA}$ and $\mathrm{Pb}(\mathrm{II}) / \mathrm{FA}$ systems was linked to the $\mathrm{H}^{+} / \mathrm{M}^{2+}$ molar exchange ratios [i.e., $\sim 1$ for $\mathrm{Pb}^{2+}$, and $\sim 1.5$ for $\mathrm{Cu}^{2+}$, respectively (Christl et al., 2001)]. The authors linked the differences in the ternary system evolution to the possible metalinduced aggregation of their FA following the decrease in negative charge induced by metal complexation. The molar $\mathrm{H}^{+} / \mathrm{M}^{\mathrm{n}}$ ratios requires that 1 mole of complexed $\mathrm{M}^{2+}$ leads 
to the release of 1 mole of $\mathrm{H}^{+}$for $\mathrm{Pb}^{2+}$, and 0.67 mole for $\mathrm{Cu}^{2+}$, respectively (Christl et al., 2001; Heidmann et al., 2005). Hence, the reduction in negative charge due to complexation is greater for $\mathrm{Pb}^{2+}$ than $\mathrm{Cu}^{2+}$. In the case of $\mathrm{Eu}^{3+}$, Marang et al. $(2006,2008)$ and Janot et al. $(2010,2011)$ obtained $\mathrm{H}^{+} / \mathrm{Eu}^{3+}$ molar exchange ratios of $~ 1.3$, and 1.6, respectively, which are comparable to those in the $\mathrm{H}^{+} / \mathrm{Cu}^{2+}$ system, but with a higher metal charge. The reduction in negative charge is thus more important for $\mathrm{Eu}^{3+}$ than for $\mathrm{Cu}^{2+}$, and is corroborates the proposition of Heidmann et al. (2005). Interestingly, the study of Heidmann et al. (2005) was on kaolinite whereas Janot et al. $(2010,2011)$ experimented on $\alpha-\mathrm{Al}_{2} \mathrm{O}_{3}$.

Another influential parameter is HA functionality modification during sorption. To examine this, it is important to compare the proposition of Tipping et al. (1983) for the creation of extra uptake HA sites upon sorption with the results obtained by Janot et al. $(2010,2012)$ and Janot (2011). it is clear in Janot et al. (2012) that after the HA sorption experiment onto $\alpha-\mathrm{Al}_{2} \mathrm{O}_{3}$ the $\mathrm{H}^{+}$affinity for non-sorbed $\mathrm{HA}$ is lower than for the original HA. Therefore, higher $\mathrm{H}^{+}$affinity sites are present in the sorbed fraction. Applying the same reasoning on $\mathrm{Eu}(\mathrm{III}) / \mathrm{HA} / \mathrm{\alpha}-\mathrm{Al}_{2} \mathrm{O}_{3}$ system, Janot et al. (2012) proposed that the sorbed-HA complex would have a higher affinity for $\mathrm{Eu}^{3+}$ than the original HA. Therefore, the higher than anticipated degree of sorption in ternary system is not due to the 'creation of extra sorption sites', but to their accessibility following sorptive fractionation.

\subsection{The particular case of tetravalent metals}

A further complication is present with (IV) redox states, which produce tetravalent cations $\left(\mathrm{M}^{4+}\right)$, in systems in which the sequence of addition is important (Figure 5). Although an effect which depends on the addition sequence has been reported for some metals with (III) redox states, it is not long lived in Cm(III) (Wang et al., 2004). The sequence of addition is of particular importance for An(IV) (notably Th, $\mathrm{U}, \mathrm{Np}, \mathrm{Pu}$ ) undergoing strong complexation reaction with $\mathrm{HA}$ (vide ante) as the corresponding $\mathrm{An}(\mathrm{III}, \mathrm{V}, \mathrm{VI})$ may be oxidised or reduced to $\mathrm{An}(\mathrm{IV})$ in the presence of $\mathrm{HS}$ [e.g. Np(V) (Zeh et al., 1999; Artinger et al., 2000) or $\mathrm{Pu}(\mathrm{III}, \mathrm{V}, \mathrm{VI})$ (Nash et al., 1981; Sanchez et al., 1985; André and Choppin, 2000; Marquardt et al., 2004; Dardenne et al., 2009)]. It has been shown (Figure 5) that if HS is sorbed onto a mineral surface, and M(IV) is added afterwards, the classical pattern of sorption hindrance after the sorption pH-edge is observed (Takahashi et al., 1999; Reiller et al., 2002, 2005; Bouby et al., 2011). However, if M(IV) is sorbed on a mineral surface before the addition of HS (Figure 5) $\mathrm{M}(\mathrm{IV})$ sorption is much less hindered (Takahashi et al., 1999; Reiller et al., 2002, 2005). A relatively weak dependence on equilibration time has also been demonstrated (Reiller et al., 2005).. The reasons behind this addition order effect are not yet clear. It is possible that the incorporation of $\mathrm{M}^{4+}$ into the mineral structure, or into a surface precipitate, would impede its removal by HA. Alternatively, the response of tetravalent metal to the fractionation of HS may induce a very high affinity of $\mathrm{M}^{4+}$ for surface-bound $\mathrm{HA}$. 


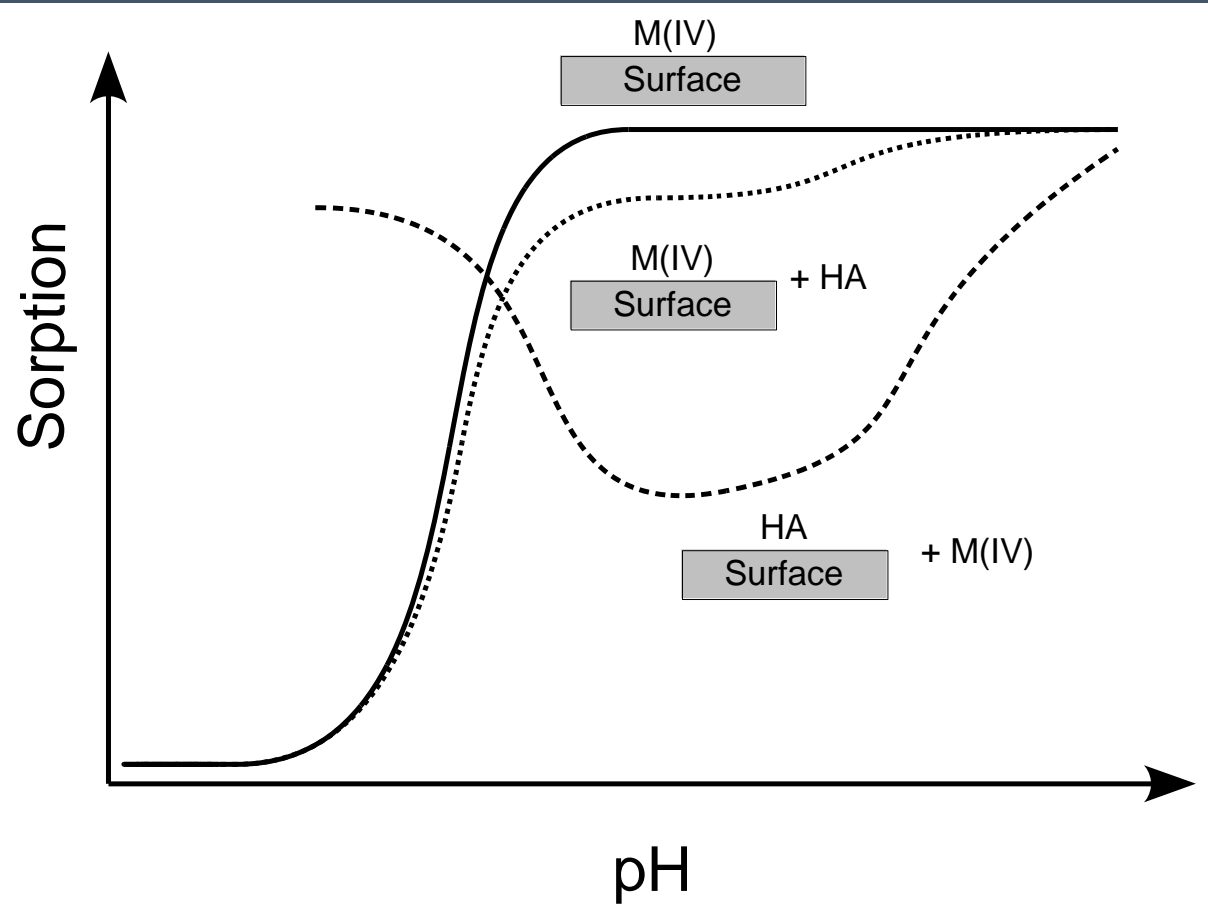

Figure 5. The effect of the addition order on $\mathrm{M}^{4+}$ sorption onto minerals in the ternary systems $\mathrm{M}(\mathrm{IV}) / \mathrm{HA} /$ surface: the solid line represents the $\mathrm{M}^{4+} \mathrm{pH}$-isotherm, dashed line represents the case where HA is equilibrated with the surface before the addition of $M(I V)$, and dotted line represents the case where $M(I V)$ is equilibrated with the surface before the addition of HA.

\section{CONCLUSIONS AND PERSPECTIVES}

The modelling of the ternary metal/HA/surface systems, at the laboratory scale or in the field, is not simple. The modelling of ternary systems using binary linear additivity meets with only partial success. This is due to the difficulty in defining an unambiguous standard state for aggregates of humic substances. Humic susbstances can form ternary complexes with metals and surfaces. The definition of ternary complexes in the case of HS is not straightforward (vide ante) but evidence exists for additional organic ligands that interact with metal/HA systems (Dierckx et al., 1994; Glaus et al., 1995; Morgenstern et al., 2000; Reiller and Buckau, 2012), and that metal/HA/oxide systems behave differently than the constituting binary systems (Tan et al., 2008; Janot et al., 2011). There is now strong evidence that a sorptive fractionation modifies the functionality of HS aggregates and hence that the ternary surface-bound and the bulk humic phases differ from those of the binary metal/HS and HS/surface systems.

Possible ways of overcoming the change in functionality following sorptive fractionation include estimating the change in free energy from the deviation between the linear additivity and the ternary system, or directly quantifying the modification through titration. Both strategies have their advantages and drawbacks: in the former, no modification of functionality is imposed when clear experimental evidence exists for it; in the latter, the 
functionality modifications rely on an operational function that is not based on a theoretical understanding of the sorptive fractionation.

The need to better understand ternary metal-NOM-surface systems and to improve the accuracy and reliability of the modelling remains. More information about the molecular phenomena that produce sorptive fractionation and change the distribution of functionality is required. Important questions about ternary systems include (1) what are the main driving forces of sorptive fractionation? (2) Is sorptive fractionation driven by a change in conformation of the NOM aggregates due to polarity change between the bulk and the surface? (3) Is sorptive fractionation driven by the sorbed NOM fraction, which shows a higher affinity for the metal, which in turn induces a change in the composition of the NOM aggregates and finally a change in conformation of NOM aggregates? (4) Is sorptive fractionation controlled by kinetics? (5) What first-order phenomena are needed to model a particular metal-HS-mineral system? Answers to all of these questions are required to provide a satisfactory model of a ternary system, especially if more than an operational view is required. As long as these questions limit our understanding of the ternary metalNOM-surface system, however, we will be unable to produce satisfactory models.

\section{ACKNOWLEDGMENT}

This review has been possible through the financing of the different work in CEA (CEA/DDIN/MRISQ and CEA/DDIN/RSTB). The reviewers and editors are acknowledged for kind polishing of the Frenglish, and for useful comments and suggestions.

\section{REFERENCES}

Achard, F.K. (1786) Chemische Untersuchung des Torfs. Chemische Annalen für die Freunde der Naturlehre, Arzneygelahrtheit, Haushaltungskunst und Manufacturen, 2, 391-403.

Aiken, G.R., and Malcolm, R.L. (1987) Molecular weight of aquatic fulvic acids by vapor pressure osmometry. Geochimica et Cosmochimica Acta, 51, 2177-2184.

Aiken, G.R., McKnight, D., Wershaw, R.L., and MacCarthy, P. (1985) Humic Substances in Soil, Sediment and Water. 692 p. Wiley-Intersciences, New-York, NY, USA.

Ali, M.A., and Dzombak, D.A. (1996) Competitive sorption of simple organic acids and sulfate on goethite. Environmental Science \& Technology, 30, 1061-1071.

Alliot, C., Vitorge, P., Bion, L., and Mercier, F. (2005a) Effect of aqueous acetic, oxalic and carbonic acids on the adsorption of uranium(VI) onto $\alpha$-alumina. New Journal of Chemistry, 29, 1409-1415.

Alliot, C., Bion, L., Mercier, F., Vitorge, P., and Toulhoat, P. (2005b) Effect of aqueous acetic, oxalic and carbonic acids on the adsorption of americium onto $\alpha$-alumina. Radiochimica Acta, 93, 435-442.
Alliot, C., Bion, L., Mercier, F., and Toulhoat, P. (2006) Effect of aqueous acetic, oxalic, and carbonic acids on the adsorption of europium(III) onto $\alpha$-alumina. Journal of Colloid and Interface Science, 298, 573-581.

Amal, R., Raper, J.A., and Waite, T.D. (1992) Effect of fulvic acid adsorption on the aggregation kinetics and structure of hematite particles. Journal of Colloid and Interface Science, 151, 244-257.

André, C., and Choppin, G.R. (2000) Reduction of $\mathrm{Pu}(\mathrm{V})$ by humic acid. Radiochimica Acta, 88, 613-616.

Artinger, R., Marquardt, C.M., Kim, J.I., Seibert, A., Trautmann, N., and Kratz, J.V. (2000) Humic colloidborne $\mathrm{Np}$ migration: Influence of the oxidation state. Radiochimica Acta, 88, 609-612.

Au, K.K., Penisson, A.C., Yang, S.L., and O’Melia, C.R. (1999) Natural organic matter at oxide/water interfaces: Complexation and conformation. Geochimica et Cosmochimica Acta, 63, 2903-2917.

Avena, M.J., and Koopal, L.K. (1998) Desorption of humic acids from an iron oxide surface. Environmental Science \& Technology, 32, 2572-2577. 


\section{P. E. Reiller. Modelling Metal-Humic Substances/Surface Systems: Reasons for Success, Failure and}

Possible Routes for Peace of Mind

Avena, M.J., and Koopal, L.K. (1999) Kinetics of humic acid adsorption at solid water interface. Environmental Science \& Technology, 33, 2739-2744.

Baalousha, M., and Lead, J.R. (2007) Characterization of natural aquatic colloids $(<5 \mathrm{~nm})$ by flow-field flow fractionation and atomic force microscopy. Environmental Science \& Technology, 41, 1111-1117.

Beneš, P. (2009) Radiotracer study of thorium complexation with humic acid at $\mathrm{pH} 2-11$ using freeliquid electrophoresis. Radiochimica Acta, 97, 273-281.

Blaakmeer, J., Böhmer, M.R., Cohen Stuart, M.A., and Fleer, G.J. (1990) Adsorption of weak polyelectrolytes on highly charged surfaces: Poly(acrylic acid) on polystyrene latex with strong cationic groups. Macromolecules, 23, 2301 2309.

Blesa, M.A., Maroto, A.J.G., and Regazzoni, A.E. (1984) Boric adsorption on magnetite and zirconium dioxide. Journal of Colloid and Interface Science, 99, 32-40.

Böhmer, M.R., Evers, O.A., and Scheutjens, J.M.H.M. (1990) Weak polyelectrolytes between 2 surfaces: Adsorption and stabilization. Macromolecules, 23, 22882301.

Booth, F. (1951) The dielectric constant of water and the saturation effect. Journal of Chemical Physics, 19, 391-394.

Borah, J. M., Sarma, J., and Mahiuddin, S. (2011) Adsorption comparison at the alpha-alumina/water interface: 3,4-Dihydroxybenzoic acid vs. catechol. Colloids and Surfaces A: Physicochemical and Engineering Aspects, 387, 50-56.

Bouby, M., Manh, T.N., Geckeis, H., Scherbaum, F., and Kim, J.I. (2002) Characterization of aquatic colloids by a combination of LIBD and ICP-MS following the size fractionation. Radiochimica Acta, 90, 727-732.

Bouby, M., Geckeis, H., Lützenkirchen, J., Mihai, S., and Schäfer, T. (2011) Interaction of bentonite colloids with $\mathrm{Cs}, \mathrm{Eu}, \mathrm{Th}$ and $\mathrm{U}$ in presence of humic acid: A flow field-flow fractionation study. Geochimica et Cosmochimica Acta, 75, 3866-3880.

Bradbury, M.H., and Baeyens, B. (2002) Sorption of Eu on $\mathrm{Na}^{-}$and Ca-montmorillonites: Experimental investigations and modelling with cation exchange and surface complexation. Geochimica et Cosmochimica Acta, 66, 2325-2334.

Bradbury, M.H., and Baeyens, B. (2005a) Modelling the sorption of $\mathrm{Mn}(\mathrm{II}), \mathrm{Co}(\mathrm{II}), \mathrm{Ni}(\mathrm{II}), \mathrm{Zn}(\mathrm{II}), \mathrm{Cd}(\mathrm{II}), \mathrm{Eu}(\mathrm{III})$, Am(III), Sn(IV), Th(IV), $\mathrm{Np}(\mathrm{V})$ and $\mathrm{U}(\mathrm{VI})$ on montmorillonite: Linear free energy relationships and estimates of surface binding constants for some selected heavy metals and actinides. Geochimica et Cosmochimica Acta, 69, 875-892.
Bradbury, M.H., and Baeyens, B. (2005b) Modelling the sorption of $\mathrm{Mn}(\mathrm{II}), \mathrm{Co}(\mathrm{II}), \mathrm{Ni}(\mathrm{II}), \mathrm{Zn}(\mathrm{II}), \mathrm{Cd}(\mathrm{II}), \mathrm{Eu}(\mathrm{III})$, Am(III), Sn(IV), Th(IV), $\mathrm{Np}(\mathrm{V})$ and $\mathrm{U}(\mathrm{VI})$ on montmorillonite: Linear free energy relationships and estimates of surface binding constants for some selected heavy metals and actinides (vol 69, pg 875, 2005). Geochimica et Cosmochimica Acta, 69, 5391-5392.

Bradbury, M.H., and Baeyens, B. (2009) Sorption modelling on illite. Part II: Actinide sorption and linear free energy relationships. Geochimica et Cosmochimica Acta, 73, 1004-1013.

Bradbury, M.H., Baeyens, B., Geckeis, H., and Rabung, T. (2005) Sorption of $\mathrm{Eu}(\mathrm{III}) / \mathrm{Cm}(\mathrm{III})$ on $\mathrm{Ca}$ montmorillonite and Na-illite. Part 2: Surface complexation modelling. Geochimica et Cosmochimica Acta, 69, 5403-5412.

Caceci, M.S., and Billon, A. (1990) Evidence for large organic scatterers (50-200 nm diameter) in humic acid samples. Organic Geochemistry, 15, 335-350.

Chibowski, S., and Wisniewska, M. (2002) Study of electrokinetic properties and structure of adsorbed layers of polyacrylic acid and polyacrylamide at $\mathrm{Fe}_{2} \mathrm{O}_{3}$-polymer solution interface. Colloids and Surfaces A: Physicochemical and Engineering Aspects, 208, 131-145.

Chin, Y.P., Aiken, G., and O’Loughlin, E. (1994) Molecular-weight, polydispersity, and spectroscopic properties of aquatic humic substances. Environmental Science \& Technology, 28, 1853-1858.

Christl, I., Milne, C.J., Kinniburgh, D.G., and Kretzschmar, R. (2001) Relating ion binding by fulvic and humic acids to chemical composition and molecular size. 2. Metal binding. Environmental Science \& Technology, 35, 2512-2517.

Christl, I., and Kretzschmar, R. (2001) Interaction of copper and fulvic acid at the hematite-water interface. Geochimica et Cosmochimica Acta, 65, 3435-3442.

Christl, I., and Kretzschmar, R. (2007) C-1s NEXAFS spectroscopy reveals chemical fractionation of humic acid by cation-induced coagulation. Environmental Science \& Technology, 41, 1915-1920.

Claret, F., Schäfer, T., Brevet, J., and Reiller, P.E. (2008) Fractionation of Suwannee River fulvic acid and Aldrich humic acids on $\alpha-\mathrm{Al}_{2} \mathrm{O}_{3}:$ spectroscopic evidence. Environmental Science \& Technology, 42, 8809-8815.

Czerwinski, K.R., Buckau, G., Scherbaum, F., and Kim, J.I. (1994) Complexation of the uranyl ion with aquatic humic acid. Radiocbimica Acta, 65, 111-119.

Czerwinski, K.R., Kim, J.I., Rhee, D.S., and Buckau, G. (1996) Complexation of trivalent actinides ions $\left(\mathrm{Am}^{3+}\right.$, $\mathrm{Cm}^{3+}$ ) with humic acids: the effect of ionic strength. Radiochimica Acta, 72, 179-187. 


\section{P. E. Reiller. Modelling Metal-Humic Substances/Surface Systems: Reasons for Success, Failure and}

Possible Routes for Peace of Mind

d'Orlyé, F., and Reiller, P.E. (2012) Contribution of capillary electrophoresis to an integrated vision of humic substances size and charge characterizations. Journal of Colloid and Interface Science, 368, 231-240.

Dalang, F., Buffle, J., and Haerdl, W. (1984) Study of the influence of fulvic substances on the adsorption of copper(II) ions at the kaolinite surface. Environmental Science \& Technology, 18, 135-141.

Dardenne, K., Seibert, A., Denecke, M.A., and Marquardt, C.M. (2009) Plutonium(III,IV,VI) speciation in Gorleben groundwater using XAFS. Radiochimica Acta, 97, 91-97.

Davis, J.A., and Leckie, J.O. (1978) Effect of adsorbed complexing ligands on trace metal uptake by hydrous oxides. Environmental Science \& Technology, 12, 1309-1315.

Davis, J.A., and Gloor, R. (1981) Adsorption of dissolved organics in lake water by aluminum oxide. Effect of molecular weight. Environmental Science \& Technology, 15, 1223-1229.

Davis, J.A., and Kent, D.B. (1990) Surface complexation modeling in aqueous geochemistry. In M.F. Hochella, and A.F. White, Eds. Mineral-Water Interface Geochemistry, 23, p. 177-260. Mineralogical Society of America, Washington DC, USA.

Dierckx, A., Maes, A., and Vancluysen, J. (1994) Mixed complex formation of $\mathrm{Eu}^{3+}$ with humic acid and a competing ligand. Radiochimica Acta, 66/67, 149-156.

Dzombak, D.A., and Morel, M.M. (1990) Surface Complexation Modelling. John Wiley \& Sons, New-York, NY, USA.

Evanko, C.R., and Dzombak, D.A. (1998) Influence of structural features on sorption of NOM-analogue organic acids to goethite. Environmental Science \& Technology, 32, 2846-2855.

Fairhurst, A.J., Warwick, P., and Richardson, S. (1995) The influence of humic-acid on the adsorption of europium onto inorganic colloids as a function of $p \mathrm{H}$. Colloids and Surfaces A: Physicochemical and Engineering Aspects, 99, 187-199.

Filius, J.D., Lumsdon, D.G., Meeussen, J.C.L., Hiemstra, T., and van Riemsdijk, W.H. (2000) Adsorption of fulvic acid on goethite. Geochimica et Cosmochimica Acta, 64, 5160 .

Fujikawa, Y., Zheng, J., Cayer, I., Sugahara, M., Takigami, H., and Kudo, A. (1999) Strong association of fallout plutonium with humic and fulvic acid as compared to uranium and ${ }^{137} \mathrm{Cs}$ in Nishiyama soils from Nagasaki, Japan. Journal of Radioanalytical and Nuclear Chemistry, 240, 69-74.

Ghabbour, E.A., and Davies, G. (2001) Humic Substances. Structures, Models and Functions. 387 p. The Royal Society of Chemistry, Cambridge, UK.
Glaus, M.A., Hummel, W., and van Loon, L.R. (1995) Stability of mixed-ligand complexes of metal ions with humic substances and low molecular weight ligands. Environmental Science \& Technology, 29, 2150-2153.

Gu, B., Schmitt, J., Chem, Z., Liang, L., and McCarthy, J.F. (1994) Adsorption and desorption of natural organic matter on iron oxide: Mechanisms and models. Environmental Science \& Technology, 28, 38-46.

Gu, B., Schmitt, J., Chem, Z., Liang, L., and McCarthy, J.F. (1995) Adsorption and desorption of different organic matter fraction on iron oxide. Geochimica et Cosmochimica Acta, 59, 219-229.

Heidmann, I., Christl, I., and Kretzschmar, R. (2005) Sorption of $\mathrm{Cu}$ and $\mathrm{Pb}$ to kaolinite-fulvic acid colloids: Assessment of sorbent interactions. Geochimica et Cosmochimica Acta, 69, 1675-1686.

Hiemstra, T., van Riemsdijk, W.H., and Bolt, G.H. (1989a) Multisite proton adsorption modeling at the solid/solution interface of (hydr)oxides: A new approach. I. Model description and evaluation of intrinsic reaction constants. Journal of Colloid and Interface Science, 133, 91-104.

Hiemstra, T., de Wit, J.C.M., and van Riemsdijk, W.H. (1989b) Multisite proton adsorption modeling at the solid/solution interface of (hydr)oxides: A new approach. II. Application to various important (hydr)oxides. Journal of Colloid and Interface Science, 133, 105-117.

Hummel, W. (1997) Binding models for humic substances. In I. Grenthe, and I. Puigdomènech, Eds. Modelling in Aquatic Chemistry, p. 153-206. OECD's Nuclear Energy Agency, Paris, France.

Hur, J., and Schlautman, M.A. (2003) Molecular weight fractionation of humic substances by adsorption onto minerals. Journal of Colloid and Interface Science, 264, 313321.

Hur, J., and Schlautman, M.A. (2004a) Influence of humic substance adsorptive fractionation on pyrene partitioning to dissolved and mineral-associated humic substances. Environmental Science \& Technology, 38, 58715877.

Hur, J., and Schlautman, M.A. (2004b) Effects of pH and phosphate on the adsorptive fractionation of purified Aldrich humic acid on kaolinite and hematite. Journal of Colloid and Interface Science, 277, 264-270.

Irving, H., and Williams, R.J.P. (1948) Order of stability of metal complexes. Nature, 162, 746-747.

Janot, N. (2011) Influence de la matière organique naturelle et des surfaces minérales sur la spéciation des radionucléides en contexte environnemental. Géochimie Fondamentale et Appliquée, PhD, p. 183. Institut de Physique du Globe de Paris, Université Denis Diderot (Paris VII), http://tel.archives-ouvertes.fr/tel00643374/fr/, Paris, France. 


\section{P. E. Reiller. Modelling Metal-Humic Substances/Surface Systems: Reasons for Success, Failure and}

Possible Routes for Peace of Mind

Janot, N., Reiller, P.E., Korshin, G.V., and Benedetti, M.F. (2010) Using spectrophotometric titrations to characterize humic acid reactivity at environmental concentration. Environmental Science \& Technology, 44, 6782-6788.

Janot, N., Benedetti, M.F., and Reiller, P.E. (2011) Colloidal $\alpha-\mathrm{Al}_{2} \mathrm{O}_{3}$, europium(III) and humic substances interactions: A macroscopic and spectroscopic study. Environmental Science \& Technology, 45, 3224-3230.

Janot, N., Reiller, P.E., Zheng, X., Croué, J.-P., and Benedetti, M.F. (2012) Characterization of humic acid reactivity modifications due to adsorption onto $\alpha-\mathrm{Al}_{2} \mathrm{O}_{3}$. Water Research, 46, 731-740.

Johnson, W.P., Bao, G.B., and John, W.W. (2002) Specific UV absorbance of Aldrich humic acid: changes during transport in aquifer sediment. Environmental Science \& Technology, 36, 608-616.

Kaiser, K., and Zech, W. (1997) Competitive sorption of dissolved organic matter fractions to soils and related mineral phases. Soil Science Society of America Journal, 61, 6469.

Kaiser, K., and Guggenberger, G. (2000) The role of DOM sorption to mineral surfaces in the preservation of organic matter in soils. Organic Geochemistry, 31, 711-725.

Kerndorff, H., and Schnitzer, M. (1980) Sorption of metals on humic acid. Geochimica et Cosmochimica Acta, 44, 1701-1708.

Kim, J.I., and Sekine, T. (1991) Complexation of neptunium(V) with humic acid. Radiochimica Acta, 55, 187-192.

Kim, S., Simpson, A.J., Kujawinski, E.B., Freitas, M.A., and Hatcher, P.G. (2003) High resolution electrospray ionization mass spectrometry and 2D solution NMR for the analysis of DOM extracted by $\mathrm{C}-18$ solid phase disk. Organic Geochemistry, 34, 1325-1335.

Kinniburgh, D.G., van Riemsdijk, W.H., Koopal, L.K., Borkovec, M., Benedetti, M.F., and Avena, M.J. (1999) Ion binding to natural organic matter: competition, heterogeneity, stoichiometry and thermodynamic consistency. Colloids and Surfaces A: Physicochemical and Engineering Aspects, 151, 147-166.

Krepelova, A., Sachs, S., and Bernhard, G. (2006) Uranium(VI) sorption onto kaolinite in the presence and absence of humic acid. Radiochimica Acta, 94, 825-833.

Kujawinski, E.B., Hatcher, P.G., and Freitas, M.A. (2002a) High-resolution Fourier transform ion cyclotron resonance mass spectrometry of humic and fulvic acids: Improvements and comparisons. Analytical Chemistry, 74, 413-419.

Kujawinski, E.B., Freitas, M.A., Zang, X., Hatcher, P.G., Green-Church, K.B., and Jones, R.B. (2002b) The application of electrospray ionization mass spectrometry (ESI MS) to the structural characterization of natural organic matter. Organic Geochemistry, 33, 171-180.
Lavoisier, A.L. (1789) Traité Elémentaire de Chimie. Présenté dans un Ordre Nouveau et d'après des Découvertes Modernes. Tome Premier. 322 p. Cuchet, Paris, France.

Lenhart, J.J., and Honeyman, B.D. (1999) Uranium(VI) sorption to hematite in the presence of humic acid. Geochimica et Cosmochimica Acta, 63, 2891-2901.

MacCarthy, P. (2001a) The principles of humic substances: An introduction to the first principle. In E.A. Ghabbour, and G. Davies, Eds. Humic Substances: Structures, Models And Functions, p. 19-30. The Royal Society of Chemistry, Cambridge, UK.

MacCarthy, P. (2001b) The principles of humic substances. Soil Science, 166, 738-751.

Mahara, Y., and Miyahara, S. (1984) Residual plutonium migration in soil of Nagasaki. Journal of Geophysical Research, 89, 7931-7936.

Mahara, Y., Kudo, A., Kauri, T., Santry, D.C., and Miyahara, S. (1988) Mobile $\mathrm{Pu}$ in reservoir sediments of Nagasaki, Japan. Health Physics, 54, 107-111.

Mahara, Y., and Kudo, A. (1995) Plutonium released by the Nagasaki A-bomb: Mobility in the environment. Applied Radiation and Isotopes, 46, 1191-1201.

Manning, T.J., and Bennett, D.M. (2000) Aggregation studies of humic acid using multiangle laser light scattering. The Science of the Total Environment, 257, 171176.

Marang, L., Reiller, P., Pepe, M., and Benedetti, M.F. (2006) Donnan membrane approach: From equilibrium to dynamic speciation. Environmental Science \& Technology, 40, 5496-5501.

Marang, L., Reiller, P.E., Eidner, S., Kumke, M.U., and Benedetti, M.F. (2008) Combining spectroscopic and potentiometric approaches to characterize competitive binding to humic substances. Environmental Science \& Technology, 42, 5094-5098.

Marmier, N., and Fromage, F. (2000) Sorption of Cs(I) on magnetite in the presence of silicates. Journal of Colloid and Interface Science, 223, 83-88.

Marquardt, C.M., Seibert, A., Artinger, R., Denecke, M.A., Kuczewski, B., Schild, D., and Fanghänel, T. (2004) The redox behaviour of plutonium in humic rich groundwater. Radiochimica Acta, 92, 617-623.

Matsunaga, T., Nagao, S., Ueno, T., Takeda, S., Amano, H., and Tkachenko, Y. (2004) Association of dissolved radionuclides released by the Chernobyl accident with colloidal materials in surface water. Applied Geochemistry, 19, 1581-1599

Maurice, P.A., and Namjesnik-Dejanovic, K. (1999) Aggregate structures of sorbed humic substances observed in aqueous solution. Environmental Science \& Technology, 33, 1538-1541. 


\section{P. E. Reiller. Modelling Metal-Humic Substances/Surface Systems: Reasons for Success, Failure and}

Possible Routes for Peace of Mind

McCarthy, J.F., Sanford, W.E., and Stafford, P.L. (1998a) Lanthanide field tracers demonstrate enhanced transport of transuranic radionuclides by natural organic matter. Environmental Science \& Technology, 32, 3901-3906.

McCarthy, J.F., Czerwinski, K.R., Sanford, W.E., Jardine, P.M., and Marsh, J.D. (1998b) Mobilization of transuranic radionuclides from disposal trenches by natural organic matter. Journal of Contaminant Hydrology, 30, 49-77.

Meier, M., Namjesnik-Dejanovic, K., Maurice, P., Chin, Y.-P., and Aiken, G.R. (1999) Fractionation of aquatic natural organic matter upon sorption to goethite and kaolinite. Chemical Geology, 157, 275-284.

Mesuere, K., and Fish, W. (1992) Chromate and oxalate adsorption on goethite. 1. Calibration of surface complexation models. Environmental Science \& Technology, 26, 2357-2364.

Morgenstern, M., Klenze, R., and Kim, J.I. (2000) The formation of mixed-hydroxo complexes of $\mathrm{Cm}(\mathrm{III})$ and Am(III) with humic acid in the neutral $\mathrm{pH}$ range. Radiochimica Acta, 88, 7-16.

Motellier, S., Ly, J., Gorgeon, L., Charles, Y., Hainos, D., Meier, P., and Page J. (2003) Modelling of the ionexchange properties and indirect determination of the interstitial water composition of an argillaceous rock. Application to the Callovo-Oxfordian low-water-content formation. Applied Geochemistry 18, 1517-1530.

Murphy, E.M., Zachara, J.M., Smith, S.C., Phillips, J.L., and Wietsma, T.W. (1994) Interaction of hydrophobic organic compounds with mineral bound humic substances. Environmental Science \& Technology, 28, 12911299.

Murphy, R.J., Lenhart, J.J., and Honeyman, B.D. (1999) The sorption of thorium (IV) and uranium (VI) to hematite in the presence of natural organic matter. Colloids and Surfaces A: Physicochemical and Engineering Aspects, 157, 47-62.

Nachtegaal, M. (2003) The influence of competing sorbents on the dynamic and mechanisms of metal reactions in natural systems: a multi-scale approach. Plant and Soil Sciences, p. 205. University of Delaware, Newark, DE, USA.

Namjesnik-Dejanovic, K., and Maurice, P.A. (2000) Conformations and aggregate structures of sorbed natural organic matter on muscovite and hematite. Geochimica et Cosmochimica Acta, 65, 1047-1057.

Namjesnik-Dejanovic, K., Maurice, P.A., Aiken, G.R., Cabaniss, S., Chin, Y.P., and Pullin, M.J. (2000) Adsorption and fractionation of a muck fulvic acid on kaolinite and goethite at $\mathrm{pH}$ 3.7, 6, and 8. Soil Science, 165, 545-559.

Nash, K.L., and Choppin, G.R. (1980) Interaction of humic and fulvic acids with Th(IV). Journal of Inorganic and Nuclear Chemistry, 42, 1045-1050.
Nash, K.L., Fried, S., Friedman, A.M., and Sullivan, J.C. (1981) Redox behavior, complexing, and adsorption of hexavalent actinides by humic acid and selected clays. Stiring marine disposal of high-level radioactive waste. Environmental Science \& Technology, 15, 834-837.

Nebbioso, A., and Piccolo, A. (2011) Basis of a humeomics science: Chemical fractionation and molecular characterization of humic biosuprastructures. Biomacromolecules, 12, 1187-1199.

Nebbioso, A., and Piccolo, A. (2012) Advances in humeomics: Enhanced structural identification of humic molecules after size fractionation of a soil humic acid. Analytica Chimica Acta, 720, 77-90.

Ochs, M., Cosovic, B., and Stumm, W. (1994) Coordinative and hydrophobic interaction of humic substances with hydrophilic $\mathrm{Al}_{2} \mathrm{O}_{3}$ and hydrophobic mercury surfaces. Geochimica et Cosmochimica Acta, 58, 639650.

Ogoshi, T., and Chujo, Y. (2005) Synthesis of anionic polymer-silica hybrids by controlling $\mathrm{pH}$ in an aqueous solution. Journal of Materials Chemistry, 15, 315-322.

Österberg, R., Mortensen, K., and Ikai, A. (1995) Direct observation of humic-acid clusters, a nonequilibrium system with a fractal structure. Naturwissenschaften, 82, 137-9.

Payne, T.E., Davis, J.A., and Waite, T.D. (1996) Uranium adsorption on ferrihydrite - effects of phosphate and humic acid. Radiochimica Acta, 74, 239-243.

Piccolo, A., Conte, P., and Cozzolino, A. (2000) Differences in high perfomance size exclusion chromatography between humic substances and macromolecular polymers. In E.A. Ghabbour, and G. Davies, Eds. Humic Substances: Versatile Components of Plants, Soil and Water, p. 111-124. The Royal Society of Chemistry, Cambridge, UK.

Piccolo, A., Conte, P., and Cozzolino, A. (2001) Chromatographic and spectrophotometric properties of dissolved humic substances compared with macromolecular polymers. Soil Science, 166, 174-185.

Pinheiro, J.P., Mota, A.M., d'Oliveira, J.M.R., and Martinho, J.M.G. (1996) Dynamic properties of humic matter by dynamic light scattering and voltammetry. Analytica Chimica Acta, 329, 15-24.

Pitois, A., Abrahamsen, L.G., Ivanov, P.I., and Bryan, N.D. (2008) Humic acid sorption onto a quartz sand surface: A kinetic study and insight into fractionation. Journal of Colloid and Interface Science, 325, 93-100.

Plancque, G., Amekraz, B., Moulin, V., Toulhoat, P., and Moulin, C. (2001) Molecular structure of fulvic acids by electrospray with quadrupole time-of-flight mass spectrometry. Rapid Communications in Mass Spectrometry, $15,827-835$. 


\section{P. E. Reiller. Modelling Metal-Humic Substances/Surface Systems: Reasons for Success, Failure and}

Possible Routes for Peace of Mind

Plaschke, M., Romer, J., Klenze, R., and Kim, J.I. (1999) In situ AFM study of sorbed humic acid colloids at different $\mathrm{pH}$. Colloids and Surfaces A: Physicochemical and Engineering Aspects, 160, 269-279.

Plaschke, M., Rothe, J., Schäfer, T., Denecke, M.A., Dardenne, K., Pompe, S., and Heise, K.H. (2002) Combined AFM and STXM in situ study of the influence of $\mathrm{Eu}(\mathrm{III})$ on the agglomeration of humic acid. Colloids and Surfaces A: Physicochemical and Engineering Aspects, 197, 245-256.

Pourret, O., Davranche, M., Gruau, G., and Dia, A. (2007) Rare earth elements complexation with humic acid. Chemical Geology, 243, 128-141.

Rabung, T., Stumpf, T., Geckeis, H., Klenze, R., and Kim, J.I. (2000) Sorption of Am(III) and Eu(III) onto $\gamma$ alumina: experiment and modelling. Radiochimica Acta, 88, 711-716.

Rabung, T., Pierret, M.C., Bauer, A., Geckeis, H., Bradbury, M.H., and Baeyens, B. (2005) Sorption of $\mathrm{Eu}(\mathrm{III}) / \mathrm{Cm}$ (III) on Ca-montmorillonite and $\mathrm{Na}$-illite. Part 1: Batch sorption and time-resolved laser fluorescence spectroscopy experiments. Geochimica et Cosmochimica Acta, 69, 5393-5402.

Reiller, P. (2005) Prognosticating the humic complexation for redox sensitive actinides through analogy, using the charge neutralisation model. Radiochimica Acta, 93, 43-55.

Reiller, P., Moulin, V., Casanova, F., and Dautel, C. (2002) Retention behaviour of humic substances onto mineral surfaces and consequences upon thorium (IV) mobility: case of iron oxides. Applied Geochemistry, 17, 1551-1562.

Reiller, P., Moulin, V., Casanova, F., and Dautel, C. (2003) On the study of Th(IV)-humic acid interactions by competition sorption studies with silica and determination of global interaction constants. Radiochimica Acta, 91, 513-524.

Reiller, P., Casanova, F., and Moulin, V. (2005) Influence of addition order and contact time on thorium(IV) retention by hematite in the presence of humic acids. Environmental Science \&o Technology, 39, 1641-1648.

Reiller, P., Amekraz, B., and Moulin, C. (2006) Sorption of Aldrich humic acid onto hematite: Insights into fractionation phenomena by electrospray ionization with quadrupole time-of-flight mass spectrometry. Environmental Science \& Technology, 40, 2235-2241.

Reiller, P.E., Evans, N.D.M., and Szabó, G. (2008) Complexation parameters for the actinides(IV)-humic acid system: A search for consistency and application to laboratory and field observations. Radiochimica Acta, 96, 345-358.
Reiller, P.E., Marang, L., Jouvin, D., and Benedetti, M.F. (2011a) Uranium (VI) binding to humic substances: Speciation, estimation of competition, and application to independant data. In B. Merkel, and M. Schipek, Eds. The New Uranium Mining Boom. Challenge and Lessons Learned, p. 565-572. Springer-Verlag, Berlin Heidelberg, Germany.

Reiller, P.E., Brevet, J., Nebbioso, A., and Piccolo, A. (2011b) Europium(III) complexed by HPSEC sizefractions of a vertisol humic acid: Small differences evidenced by time-resolved luminescence spectroscopy. Spectrochimica Acta Part A: Molecular and Biomolecular Spectroscopy, 78, 1173-1179.

Reiller, P.E., and Buckau, G. (2012) Impacts of humic substances on the geochemical behaviour of radionuclides. In C. Poinssot, and H. Geckeis, Eds. Radionuclide Behaviour in the Natural Environment: Science, Implications and Lessons for the Nuclear Industry (ISBN 9780857091321). Woodhead Publishing.

Rice, J.A., Tombácz, E., and Malekani, K. (1999) Application of light and X-ray scattering to characterize the fractal properties of soil organic matter. Geoderma, $\mathbf{8 8}$, 251-264.

Robertson, A.P. (1996) Goethite/humic acid interactions and their effects on copper(II) binding, PhD, p. 215. Stanford University, Palo Alto, CA, USA.

Robertson, A.P., and Leckie, J.O. (1994) Humic acid/goethite interactions and their effect on copper binding. In N. Senesi, and T.M. Miano, Eds. Humic Substances in the Global Environment and Implication on Human Health, p. 487-492. Elsevier, Amsterdam, The Netherlands.

Romanchuk, A.Y., Kalmykov, S.N., and Aliev, R.A. (2011) Plutonium sorption onto hematite colloids at femto- and nanomolar concentrations. Radiochimica Acta, 99, 137-144.

Sachs, S., Brendler, V., and Geipel, G. (2007) Uranium(VI) complexation by humic acid under neutral $\mathrm{pH}$ conditions studied by laser-induced fluorescence spectroscopy. Radiochimica Acta, 95, 103-110.

Sanchez, A.L., Murray, J.M., and Sibley, T.H. (1985) The adsorption of plutonium IV and V on goethite. Geochimica et Cosmochimica Acta, 49, 2297-2307.

Schindler, P.W. (1990) Co-adsorption of metal ions and organic ligand: formation of ternary surface complexes. In M.F. Hochella, and A.F. White, Eds. Mineral-water interface geochemistry, 23, p. 281-307. Mineralogy Society of America, Washington, DC, USA.

Schlautman, M.A., and Morgan, J.J. (1994) Adsorption of aquatic humic substances on colloidal-size aluminum oxide particles: Influence of solution chemistry. Geochimica et Cosmochimica Acta, 58, 4293-4303.

Schnitzer, M., and Skinner, S.I.M. (1966) Organo-metallic interactions in soils: 5 . Stability constants of $\mathrm{Cu}^{++}-\mathrm{Fe}^{++}$ and $\mathrm{Zn}^{++}$-fulvic acid complexes. Soil Science, 102, 361-365. 


\section{P. E. Reiller. Modelling Metal-Humic Substances/Surface Systems: Reasons for Success, Failure and}

Possible Routes for Peace of Mind

Schnitzer, M., and Skinner, S.I.M. (1967) Organo-metallic interactions in soils: 7. Stability constants of $\mathrm{Pb}^{++}-\mathrm{Ni}^{++}$, $\mathrm{Mn}^{++}, \mathrm{Co}^{++}, \mathrm{Ca}^{++}$, and $\mathrm{Mg}^{++}$-fulvic acid complexes. Soil Science, 103, 247-252.

Schulthess, C.P., and McCarthy, J.F. (1990) Competitive adsorption of aqueous carbonic and acetic acids by an aluminium oxide. Soil Science Society of America Journal, 54, 688-694.

Seibert, A., Mansel, A., Marquardt, C.M., Keller, H., Kratz, J.V., and Trautmann, N. (2001) Complexation behaviour of neptunium with humic acid. Radiochimica Acta, 89, 505-510.

Senesi, N., Rizzi, F.R., Dellino, P., and Acquafredda, P. (1997) Fractal humic acids in aqueous suspensions at various concentrations, ionic strengths, and $\mathrm{pH}$ values. Colloids and Surfaces A: Physicochemical and Engineering Aspects, 127, 57-68.

Simpson, A.J., Kingery, W.L., and Hatcher, P.G. (2003) The identification of plant derived structures in humic materials using three-dimensional NMR spectroscopy. Environmental Science \& Technology, 37, 337-342.

Sonke, J.E. (2006) Lanthanide-humic substances complexation. II. Calibration of humic ion-binding model V. Environmental Science \& Technology, 40, 74817487.

Stevenson, F.J. (1982) Humus Chemistry: Genesis, Composition, Reactions. Wiley, New York, NY, USA.

Stockdale, A., Bryan, N.D., and Lofts, S. (2011) Estimation of Model VII humic binding constants for $\mathrm{Pd}^{2+}, \mathrm{Sn}^{2+}, \mathrm{U}^{4+}, \mathrm{NpO}_{2}{ }^{2+}, \mathrm{Pu}^{4+}$ and $\mathrm{PuO}_{2}{ }^{2+}$. Journal of Environmental Monitoring, 13, 2946-2950.

Szabó, G., Guczi, J., Reiller, P.E., Miyajima, T., and Bulman, R.A. (2010) Effect of ionic strength on complexation of $\mathrm{Pu}(\mathrm{IV})$ with humic acid. Radiochimica Acta, 98, 13-18.

Szekeres, M., Tombácz, E., Ferencz, K., and Dekany, I. (1998) Adsorption of salicylate on alumina surfaces. Colloids and Surfaces A: Physicochemical and Engineering Aspects, 141, 319-325.

Takahashi, Y., Minai, Y., Ambe, S., Makide, Y., and Ambe, F. (1999) Comparison of adsorption behavior of multiple inorganic ions on kaolinite and silica in the presence of humic acid using the multitracer technique A comparison with dissolved aluminum. Geochimica et Cosmochimica Acta, 63, 815-836.

Tan, X.L., Wang, X.K., Geckeis, H., and Rabung, T. (2008) Sorption of Eu(III) on humic acid or fulvic acid bound to hydrous alumina studied by SEM-EDS, XPS, TRLFS, and batch techniques. Environmental Science \& Technology, 42, 6532-6537.
Tertre, E., Beaucaire, C., Juery, A., and Ly, J. (2010) Methodology to obtain exchange properties of the calcite surface-Application to major and trace elements: $\mathrm{Ca}(\mathrm{II})$, $\mathrm{HCO}_{3}^{-}$, and $\mathrm{Zn}(\mathrm{II})$. Journal of Colloid and Interface Science, 347, 120-126.

These, A., Winkler, M., Thomas, C., and Reemtsma, T. (2004) Determination of molecular formulas and structural regularities of low molecular weight fulvic acids by size-exclusion chromatography with electrospray ionization quadrupole time-of-flight mass spectrometry. Rapid Communications in Mass Spectrometry, 18, 1777-1786.

Tipping, E. (1981a) Adsorption by goethite $(\alpha-\mathrm{FeOOH})$ of humic substances from three different lakes. Chemical Geology, 33, 81-89.

Tipping, E. (1981b) The adsorption of aquatic humic substances by iron oxides. Geochimica et Cosmochimica Acta, 45, 191-199.

Tipping, E. (2002) Cation Binding by Humic Substances. 434 p. Cambridge University Press, Cambridge, UK.

Tipping, E., Griffith, J.R., and Hilton, J. (1983) The effect of adsorbed humic substances on the uptake of copper(II) by goethite. Croatica Chemica Acta, 56, 613-621.

Turner, D.R., Pabalan, R.T., and Bertetti, F.P. (1998) Neptunium(V) sorption on montmorillonite: An experimental and surface complexation modeling study. Clays and Clay Minerals, 46, 256-69.

van de Weerd, H., van Riemsdijk, W.H., and Leijnse, A. (1999) Modelling the dynamic adsorption-desorption of NOM mixture: Effects of physical and chemical heterogeneity. Environmental Science \& Technology, 33, 16751681.

van den Hoop, M.A.G.T., van Leeuwen, H.P., and Cleven, R.F.M.J. (1990) Study of the polyelectrolyte properties of humic acids by conductimetric titration. Analytica Chimica Acta, 232, 141-148.

van Dijk, H. (1971) Cation binding of humic acids. Geoderma, 5, 53-67.

Vermeer, A.W.P. (1996) Interaction between humic acid and hematite and their effects upon metal speciation, PhD, p. 199. Landbouwuniversiteit Wageningen, Wageningen, The Netherlands.

Vermeer, A.W.P., van Riemsdijk, W.H., and Koopal, L.K. (1998) Adsorption of humic acids to mineral particles. 1. Specific and electrostatic interactions. Langmuir, 14, 2810-2819.

Vermeer, A.W.P., and Koopal, L.K. (1998) Adsorption of humic acids to mineral particles. 2. Polydispersity effects with polyelectrolyte adsorption. Langmuir, 14, 4210-4216.

Vermeer, A.W.P., McCulloch, J.K., van Riemsdijk, W.H., and Koopal, L.K. (1999) Metal ion adsorption to complexes of humic acid and metal oxides: Deviation from the additivity rule. Environmental Science \& Technology, 33, 3892-3897. 
Waite, T.D., Davis, J.A., Payne, T.E., Waychunas, G.A., and $\mathrm{Xu}, \mathrm{N}$. (1994) Uranium(VI) adsorption to ferrihydrite: application of a surface complexation model. Geochimica et Cosmochimica Acta, 58, 5465-5478.

Wang, X.K., Rabung, T., Geckeis, H., Panak, P.J., Klenze, R., and Fanghänel, T. (2004) Effect of humic acid on the sorption of $\mathrm{Cm}$ (III) onto $\gamma-\mathrm{Al}_{2} \mathrm{O}_{3}$ studied by the time-resolved laser fluorescence spectroscopy. Radiochimica Acta, 92, 691-695.

Weng, L.P., van Riemsdijk, W.H., Koopal, L.K., and Hiemstra, T. (2006) Adsorption of humic substances on goethite: Comparison between humic acids and fulvic acids. Environmental Science \& Technology, 40, 7494-7500.

Weng, L.P., van Riemsdijk, W.H., and Hiemstra, T. (2007) Adsorption of humic acids onto goethite: Effects of molar mass, $\mathrm{pH}$ and ionic strength. Journal of Colloid and Interface Science, 314, 107-118.

Wershaw, R.L. (1986) A new model for humic materials and their interactions with hydrophobic organic chemicals in soil-water or sediment-water systems. Journal of Contaminant Hydrology, 1, 29.

Wershaw, R.L. (1989) Application of a membrane model to the sorptive interactions of humic substances. Environmental Health Perspectives, 83, 191-203.

Wershaw, R.L. (1993) Model for humus. Environmental Science \& Technology, 27, 814-816.

Wershaw, R.L. (1999) Molecular aggregation of humic substances. Soil Science, 164, 803-13.
Wershaw, R.L. (2000) The study of humic substances - In search of a paradigm. In E.A. Ghabbour, and G. Davies, Eds. Humic Substances. Versatile Components of Plants, Soils and Water, p. 1-7. The Royal Society of Chemistry, Cambridge, UK.

Wershaw, R.L., Leenheer, J.A., Sperline, R.P., Song, Y.A., Noll, L.A., Melvin, R.L., and Rigatti, G.P. (1995) Mechanism of formation of humus coatings on mineral surfaces. I. Evidence for multidentate binding of organicacids from compost leachate on alumina. Colloids and Surfaces A: Physicochemical and Engineering Aspects, 96, 93104.

Yoon, T.H., Johnson, S.B., and Brown, G.E. (2004) Adsorption of Suwannee River fulvic acid on aluminum oxyhydroxide surfaces: An in situ ATR-FTIR study. Langmuir, 20, 5655-5658.

Zachara, J.M., Resch, C.T., and Smith, S.C. (1994) Influence of humic substances on $\mathrm{Co}^{2+}$ sorption by a subsurface mineral separate and its mineralogic components. Geochimica et Cosmochimica Acta, 58, 553-566.

Zeh, P., Czerwinski, K.R., and Kim, J.I. (1997) Speciation of uranium in Gorleben groundwaters. Radiochimica Acta, 76, 37-44.

Zeh, P., Kim, J.I., Marquardt, C.M., and Artinger, R. (1999) The reduction of $\mathrm{Np}(\mathrm{V})$ in groundwater rich in humic substances. Radiochimica Acta, 87, 23-28.

Zhao, P.H., Zavarin, M., Leif, R.N., Powell, B.A., Singleton, M.J., Lindvall, R.E., and Kersting, A.B. (2011) Mobilization of actinides by dissolved organic compounds at the Nevada Test Site. Applied Geochemistry, 26, 308-318. 